\title{
Corporate Finance Legal Protection as a Recipient Fiduciary Warranties Made Object of Evidence in Criminal Problem
}

\author{
Tegar Firmansyah $^{1}$
}

Abstract. In a consumer financing agreement in the form of a motor vehicle then the finance company will carry out the object binding fiduciary insurance for motor vehicles which have been delivered to the consumer. Fiduciary purpose vehicle that has been delivered to the consumer is to secure the creditor on the agreements that have been made of the risk of a breakdown of installments or transferred vehicle that has been tied with the fiduciary guarantee. Mastery of objects that remain in the possession of the debtor could be used to commit a crime which causes fiduciary object used as evidence in court and until the court decision object was confiscated by the state guarantee. The research is qualitative research in the form of descriptive analysis using normative juridical approach. Legal protection against creditors under Article 20 of Act No. 42 Of 1999 regarding Fiduciary stating fiduciary fixed object fiduciary assurance follow wherever located or when objects are on the fiduciary third party then the lender has the authority to take it. Article contains the principle Droite de Suite. The legal consequences of confiscation by the state that is the position of the objects belong to the state and the object can not be used by anyone. Deprivation of fiduciary objects do not cause the voidance of fiduciary so that the debtor shall replace objects fiduciary pursuant to Article 1131 Civil Law Book.

Keywords: Legal Protection; Fiduciary; Corporate Financing; Equipment Evidence.

\section{Introduction}

Consumer financing agreement is one form of a special agreement which is subject to the provisions of Book III of the Civil Code. The main legal sources of consumer financing is the leasing agreement runs out and the conditional purchase stipulated in the Civil Code. The second source of primary law are discussed in context with consumer financing. ${ }^{2}$

Consumer financing as one form of business financing sourced from various provisions of the law, both treaty and law. Agreement is the main source of financing for consumers in terms of civil, while the law is the main legal source for consumers in terms of public financing. ${ }^{3}$

Consumer financing is a form of financing committed by financial firms, as well as activities such as leasing, factoring, and credit cards. Consumer finance arises because the needs of the parties, namely the consumer finance company, the consumer and the provider of the goods / supplier.

\footnotetext{
1 Student of Masters (S2) of Law Faculty of Law Unissula Semarang e-mail tegarfirmansyah191@yahoo.com

${ }^{2}$ Sunaryo 2009 Hukum Lembaga Pembiayaan Ed. 1. Cet. 2.Sinar Grafika Jakarta p 99.

${ }^{3}$ Muhammad Abdulkadir and Rilda Muniarti 2000 Legal and Financial Institutions Citra Aditya Bakti Bandung p 214.
} 
The subject is the parties involved in the legal relationship of consumer financing, namely consumer finance company (creditors), consumers (borrowers) and suppliers. ${ }^{4}$ Between the consumer and the supplier there is a relationship of buying and selling, in this case the conditional purchase, where the supplier as the seller sells goods to the consumer as a buyer, provided that the price / or lack of payment will be paid by a third party, namely the grantor cost. The requirement means that if for any reason the provider can not provide the cost of funds, the sale and purchase between the parties suppliers with consumers as buyers will be canceled. Because of the purchase agreement, all the provisions of the relevant purchase will apply. For example, concerning the obligation "to bear" on the part of the seller, after-sales obligation (warranty). ${ }^{5}$

Substantially, the notion of consumer financing is basically no different from consumer credit. Understanding consumer financing by A. Abdulrahman, consumer finance are loans granted to consumers to purchase consumer goods and services as distinguished from loans used for productive purposes or trade.

Such credit may contain a greater risk than ordinary trade credit, therefore, is usually given credit with a higher interest rate. ${ }^{6}$

In a consumer financing agreement in the form of a motor vehicle then the finance company will carry out the object binding fiduciary insurance for motor vehicles which have been delivered to the consumer. Fiduciary purpose vehicle that has been delivered to the consumer is to secure the creditor on the agreements that have been made of the risk of a breakdown of installments or transferred vehicle that has been tied with the fiduciary guarantee. ${ }^{7}$

Fiduciary agreement be in writing in order for holders of fiduciary sake creditors will demand the most convenient way to prove the delivery of the collateral against the debtor. The most important thing other fiduciary agreement made in writing is to anticipate the unexpected things and beyond the power of humans as the debtor dies before obtaining creditor rights. Without a valid fiduciary deed will be difficult for creditors to prove their rights to the heirs of the debtor. ${ }^{8}$

In the practice of binding the public execution in the object of collateral using fiduciary institutions are often used by banks and finance companies in the motor vehicle a credit agreement. In principle, in a credit agreement by both the bank and the finance company, the binding object collateral by using agency fiduciary is with the aim of securing the assets of the bank / company provided to customers through a credit agreement of risk borrowers unable to repay its debts to the bank or the finance company. Thus it can be said to be the object of collateral using binding fiduciary institution is a accesoir agreement, where the credit agreement were first implemented as a principal agreement. ${ }^{9}$

\footnotetext{
${ }^{4}$ Ibid p 246.

${ }^{5}$ Muhammad Abdulkadir dan Rilda Muniarti 2000 Segi Hukum Lembaga Keuangan dan Pembiayaan Citra Aditya Bakti Bandung p 167.

${ }^{6}$ Ibid p 162

${ }^{7}$ Munir Fuady 2002 Hukum Pembiayaan (Dalam Teori dan Praktek) PT. Citra Aditya Bakti Bandung p.10

${ }^{8}$ Tiong Oey Hoey 2006 Fidusia Sebagai Jaminan Unsur-Unsur Perikatan Jakarta : Ghalia Indonesia p.47

${ }^{9}$ Gunawan Widjaja \& Ahmad Yani 2000 Jaminan Fidusia Jakarta : Raja Grafindo Persada p.104
} 
In the credit agreement the consumer to the product motor vehicle with a system of lease-sale agreement, a motor vehicle as an object of fiduciary still belong to the lender to a debtor (consumer credit recipient) repay all the installments have been agreed in the lease agreement to buy the car. After the overall price of the car is paid off debtors (credit recipient) then there was a momentum shift ownership rights of the creditor (lender) to a debtor (credit recipient) with marked giving a receipt sign the settlement, the documents related to the car from the creditor to the debtor, Legal relationships that occur in consumer financing activities are always made in writing (contract) as a legal document that became the basis of the rule of law (legal certainly). Consumer financing agreement was made based on the principle of freedom of contract of the parties will form the formulation containing the rights and obligations of the consumer finance company as the provider of funds (fund lenders), and consumers as the user of funds (fund user). ${ }^{10}$

Meanwhile for the object fiduciary for their criminal cases conducted by consumers and by others for the purpose of investigation in the police has confiscated as evidence that later by the police the evidence will be handed over to the Prosecutor as evidence in the trial in court.

In a criminal case of embezzlement in court during the proceedings until the reading of the ruling of the judge's decision obtained by the decision that evidence of a motor vehicle which is the object fiduciary will be delivered to consumers while the condition these consumers are in default with the finance company and the consumer is not stay longer at the address of unknown origin and existence. The consequence is that the company can make the execution of the fiduciary security object, in accordance with sound in Article 15 paragraph 2 of Act 42 of 1999 regarding Fiduciary Law, which reads: "Fiduciary Certificates as referred to in paragraph (1) shall have the power exsecutorial same court decision that has obtained permanent legal force. "

But in fact when the finance company will take the evidence is encountering many obstacles, the Prosecutor can not submit the evidence to the finance company. Prosecutor parties cling to Amar Court Judge's decision that the evidence is to be submitted to the consumer while the consumer condition is already doing Defaults and is not known to exist. Party Prosecutor demands to be presented and the consumer must be at least a letter of authorization from the consumer, this can not be done by the finance company because the condition does not allow.

As a result of the confiscation of objects fiduciary for a criminal offense to cause damage to the recipient of fiduciary, because the object of fiduciary guarantee as collateral debt of the debtor as grantor of fiduciary seized / confiscated by the state through judicial decisions binding (incracht van gewijsde) which cause the object fiduciary that can no longer be executed if the debtor as grantor fiduciary in default or are unable to make payment on its debts.

Based on the background described, the authors are interested in making research on the Legal Protection of Financial Services As Receiver Fiduciary The Top Objects Used as Evidence In Criminal problem.

From the background of the problems described above, the formulation of the problem is as follows: What is the legal protection of finance companies as recipients

\footnotetext{
${ }^{10}$ Sunaryo 2009 Hukum Lembaga Pembiayaan Sinar Grafika Jakarta p 98.
} 
of Fiduciary objects used as evidence in criminal offenses? How is the legal status of the object fiduciary seized by the Attorney through a court ruling related to criminal cases?

\section{Research Methods}

The method used is normative, which deductively began an analysis of the clauses in the regulations related legislation. Given that the problems studied ranged in legislation and its relation to its application in practice. Data were collected by using secondary data is data obtained through library research. The literature can be: legislation, scientific works to scholars of jurisprudence (the judge's decision), and other sources. The research is qualitative research in the form of descriptive analysis.

\section{Results and Discussion}

\subsection{Legal protection against fiduciary holder in terms of fiduciary objects used as Evidence in the case of Crime.}

Legal protection is all the effort the fulfillment of rights and provision of assistance to provide security to witnesses or victims, legal protection of victims of crime as part of the protection of the public, can be realized in various forms, such as through the provision of resitusi, compensation, medical care and legal aid. ${ }^{11}$

In UUJF own no provision of article governing the fiduciary object used to commit a crime and was used by the court piha. In fiduciary creditor protection was limited to Article 20 UUJF stating that the fiduciary keep abreast of things that become the object of any fiduciary in hand the object is, the article contains the principle of droit de suite. Receiver fiduciary interests protected by the principle of droit de suite, as the lender has the authority to take the object fiduciary who are on hand or on the other side. Although in UUJF not clearly regulate the legal actions that cause the debtor objects fiduciary deprived state, but in UUJF regulate penal provisions if the debtor dispose of the object of the guarantee. The regulation stipulated in Article 36 UUJF which specifies that, "giver of fiduciary, pledge or lease the object is the object of fiduciary as referred to in Article 23, Paragraph (2) which is carried out without the prior written consent of the Receiver fiduciary, shall be punished with imprisonment for a period of 2 (two) years and a maximum fine of Rp. 50,000,000, - (fifty million. "According to $\mathrm{H}$. Salim criminal elements that must be met, so that the perpetrators can be prosecuted under this article, the Giver of fiduciary, that transfer, pledge and fiduciary rent objects without written permission recipient fiduciary. The regulation stipulated in Article 36 UUJF which specifies that, "giver of fiduciary, pledge or lease the object is the object of fiduciary as referred to in Article 23, Paragraph (2) which is carried out without the prior written consent of the Receiver fiduciary, shall be punished with imprisonment for a period of 2 (two) years and a maximum fine of Rp. 50,000,000, - (fifty million. "According to $\mathrm{H}$. Salim criminal elements that must be met, so that the perpetrators can be prosecuted under this article, the Giver of fiduciary, that transfer, pledge and

\footnotetext{
${ }^{11}$ Mukti Fajar dan Yulianto Achmad 2010 Dualisme Penelitian Hukum Normatif Dan Empiris cet.III Pustaka Pelajar Yogyakarta p.34.
} 
fiduciary rent the objects without written permission recipient fiduciary. The regulation stipulated in Article 36 UUJF which specifies that, "giver of fiduciary, pledge or lease the object is the object of fiduciary as referred to in Article 23, Paragraph (2) which is carried out without the prior written consent of the Receiver fiduciary, shall be punished with imprisonment for a period of 2 (two) years and a maximum fine of Rp. 50,000,000, - (fifty million. "According to H. Salim criminal elements that must be met, so that the perpetrators can be prosecuted under this article, the Giver of fiduciary, that transfer, pledge and fiduciary rent objects without written permission recipient fiduciary. or lease object is the object of fiduciary as referred to in Article 23, Paragraph (2) which is carried out without the prior written consent of the Receiver fiduciary, shall be punished with imprisonment for a period of 2 (two) years and a maximum fine of Rp. 50,000,000, - (fifty million. "According to H. Salim criminal elements that must be met, so that the perpetrators can be prosecuted under this article, the Giver of fiduciary, that transfer, pledge and fiduciary rent objects without written permission recipient fiduciary. or lease object is the object of fiduciary as referred to in Article 23, Paragraph (2) which is carried out without the prior written consent of the Receiver fiduciary, shall be punished with imprisonment for a period of 2 (two) years and a maximum fine of Rp. 50,000,000, - (fifty million. "According to $\mathrm{H}$. Salim criminal elements that must be met, so that the perpetrators can be prosecuted under this article, the Giver of fiduciary, that transfer, pledge and fiduciary rent objects without written permission recipient fiduciary.

Legal efforts to do the creditors in terms of fiduciary objects used as evidence in a criminal case, namely:

- Reporting themselves as victim witness The witness testimony in criminal procedural law is bound to valid evidence. One of them is the witnesses of great importance. It is expected of judges in decisions also consider the role of the victim, material loss suffered by the victim inmaterial and so on. ${ }^{12}$

- Claims for damages based on Article 1365 of the Civil Code (hereinafter the Civil Code) Claims of creditors as a fiduciary receiver repressive measures to obtain legal protection legally. Each unlawful act and bring harm to others, require a person to incur losses because mistakes to replace those losses. The lawsuit does not by default, but tort based compensation based on unlawful acts committed by the debtor under Article 1365 of the Civil Code.

\subsection{Legal Status of Objects Fiduciary who Seized by the Attorney Through A Court decision relating to Case of Crime}

Definition of objects fiduciary in Article 1 (4) UUJF stating that the object is anything that can be owned and transferred, both tangible and intangible, registered and unregistered, moving or not moving can not be encumbered encumbrance and a mortgage. Fiduciary represents the transfer of ownership of an object on the basis of trust. Objects fiduciary who are in possession of the debtor could be used to commit a crime or a criminal act by the fiduciary debtor objects may be confiscated or seized by

\footnotetext{
${ }^{12}$ Lilik Muliyadi 2012 Hukum Acara Pidana Indonesia Suatu Tinjauan Khusus Terhadap Surat Dakwaan Eksepsi dan Putusan Peradilan cet. 4 Citra Aditya Bakti Bandung p. 20.
} 
the state if the debtor objects fiduciary receipts in a tort. According to Article 1 (4) of the Regulation of the Minister of Justice and Human Rights of the Republic of ndonesia No. 16 of 2014 on the Procedures for Management of objects confiscated State and Goods Confiscated by the State provide a definition of goods ramasan countries namely: "Goods Confiscated by the State, hereinafter referred to Baran are objects confiscated by court decision that has gained legal force and equipment are stated confiscated for the state. "An object to be seized by the state must first have a court decision that remain. Factors fiduciary can be seized by the state if preceded with foreclosure action associated with the object of collateral used to do crime. In Article 39 of Act No. 8 of 1981 on Criminal Proceedings (hereinafter referred to the Criminal Procedure Code) mentioned objects may be subject to foreclosure are:

- Objects or bill suspect or defendant allegedly obtained all or part of a criminal action or as a result of a criminal act;

- Objects that have been used directly for committing or preparing for it;

- Things that used to obstruct the investigation of criminal offenses;

- Objects that are specially made or intended committing a crime

- Other objects that have a direct relation with criminal offenses committed.

Deprivation object fiduciary provide juridical consequences that harm the recipient fiduciary for the transitional object of fiduciary cause loss of property rights owned by the creditor to execute the object and the position of objects deprived of the state belongs to the state and the object can not be used by anyone in accordance with the provisions of Article 44 paragraph (2) Criminal Procedure Code. Related objects fiduciary deprived state, there are no regulations concerning it. Deprivation of the fiduciary object does not cause the voidance of fiduciary, where abolishment of fiduciary under Article 25 paragraph (1) UUJF which states that: Fiduciary void due to the following matters:

- The abolition of the debt secured by a fiduciary;

- Waiver of Fiduciary by the beneficiary;

- Destruction of objects that become the object of fiduciary.

Under the provisions of that Article, the deprivation of fiduciary object by the state does not eliminate the debt that has burdened fiduciary, so borrowers still have to perform its obligation to pay off its debts. Nevertheless, the position of creditors in this case is very dangerous if the debt of the debtor have expired and the debtor does not make payments on its debt which led to the execution of fiduciary object can not be performed because the object is not in possession of the debtor but deprived countries. Objects that have been deprived of their fiduciary state can not be used by anyone, so that the debtor shall be responsible for the actions dlakukannya by providing replacement jaminn pursuant to Article 1131 of the Civil Code which states that: "All items of movable and immovable belonging to the debtor, either already exist or will exist, a guarantee to the engagements of individual debtors that." Under that Article, the debtor has an obligation to replace objects such guarantee with objects or goods equivalent or more of the objects that have been deprived of their fiduciary earlier to guarantee repayment of the debtor. The article reflects on the general guarantee for the creditor against the debtor's debt. the debtor has an obligation to replace the collateral objects with objects or items of equal or more than 
the objects that have been deprived of their fiduciary earlier to guarantee repayment of the debtor. The article reflects on the general guarantee for the creditor against the debtor's debt. the debtor has an obligation to replace the collateral objects with objects or items of equal or more than the objects that have been deprived of their fiduciary earlier to guarantee repayment of the debtor. The article reflects on the general guarantee for the creditor against the debtor's debt.

\section{Closing}

\subsection{Conclusion}

- Legal protection acquired by the recipient of fiduciary if the fiduciary objects seized by the state caused by the unlawful act of fiduciary giver can be repressive legal protection if the court decision has permanent legal force by making a claim for damages for a tort based on Article 1365 of the Civil Code.

- The legal status of objects fiduciary deprived state, ie objects fiduciary who already have permanent legal force based on court decisions, the position of the object fiduciary becomes the property of the state and donor fiduciary obligation to replace the object of fiduciary with objects equivalent to the objects fiduciary who has deprived.

\subsection{Suggestion}

- Givers should fiduciary acting in good faith to provide compensation to the fiduciary recipient of the value of assets as collateral if tort giver cause objects Fiduciary deprived state

- Fiduciary giver should give top replacement fiduciary objects that have been deprived of the country with the object of equivalent value.

\section{References}

[1] Darwan Prinst 1998 Hukum Acara Pidana dalam Praktik Djambatan Jakarta

[2] Gunawan Widjaja \& Ahmad Yani 2000 Jaminan Fidusia Raja Grafindo Persada Jakarta.

[3] Jimly Asshiddiqie 2007 Konstitusi Dan Ketatanegaraan Indonesia Kontemporer The Biography Institute Bekasi

[4] Johannes Ibrahim 2004 Mengupas Tuntas Kredit Komersial dan Konsumtif Dalam Perjanjian Kredit Bank (Perspektif Hukum dan Ekonomi) Mandar Maju Bandung

[5] Mariam Darus Badrulzaman 1991 Bab Tentang Kredit Verband Gadai \& Fidusia Citra Aditya Bakti Bandung

[6] Muhammad Abdulkadir dan Rilda Muniarti 2000 Segi Hukum Lembaga Keuangan dan Pembiayaan Citra Aditya Bakti Bandung

[7] Muktar Djasman 2009 Perusahaan Pembiayaan dan Perjanjian Sewa Beli Mitra Ilmu Surabaya

[8] Muladi B 2004 Kapita Selekta Sistem Peradilan Pidana Cetakan Kedua :Badan Penerbit Universitas Diponegoro Semarang 
[9] Munir Fuadi II 2013 Hukum Jaminan Utang Erlangga Jakarta

[10] Munir Fuady 2002 Hukum Pembiayaan (Dalam Teori dan Praktek) PT. Citra Aditya Bakti Bandung

[11] Munir Fuady 2006 Hukum Tentang Pembiayaan PT.Citra Aditya Bakti Bandung

[12] Munir Fuady 2007 Dinamika Teori Hukum Dinamika Teori Hukum Ghalia Indonesia Bogor

[13] Siswantoro Sunarso 2004 Penegakan Hukum Psikotropika PT Raja Grafindo Persada Jakarta

[14] Soerjono Soekanto 2010 Faktor-Faktor Yang Mempengaruhi Penegakan Hukum Rajawali Pers Jakarta

[15] Sri Soedewi Masjchoen Sofwan 1977 Beberapa masalah Pelaksanaan Lembaga Jaminan Khususnya Fiducia di Dalam dan Pelaksanaannya di Indonesia Fakultas Hukum Universitas Gadjah mada Yogyakarta

[16] Sri Soedewi Masjoen Sofyan 1995 Hukum dan Jaminan Perorangan Liberty Yogyakarta

[17] Sudikno Mertokusumo Dan A.Pitlo 1993 Bab-Bab Tentang Penemuan Hukum PT.Aditya Bakti Yogyakarta

[18] Sunaryo 2009 Hukum Lembaga Pembiayaan Sinar Grafika Jakarta

[19] Tan Kamello 2007 Hukum Jaminan Fidusia Suatu Kebutuhan yang Didambakan Alumni Bandung

[20] Tiong Oey Hoey 2006 Fidusia Sebagai Jaminan Unsur-Unsur Perikatan Ghalia Indonesia Jakarta

[21] Yurizal 2011 Aspek Pidana Dalam Undang-Undang No 42 Tahun 1999 Media Nusa Creative Surabaya 